\title{
EFFECT OF ZINC AND PHOSPHORUS FERTILIZATION ON RICE CROP UNDER SALINE SOIL CONDITIONS
}

\author{
Gharib, H. S. ${ }^{1}$; B. A. A. Zayed ${ }^{2}$; S. Gh. R. Sorour ${ }^{1}$ and \\ Amira M. E. Okasha ${ }^{2}$ \\ 1. Agronomy Dept., Fac. Agric., Kafrelshiekh University, Egypt. \\ 2. Rice Research and training center, Sakha, Kafrelshiekh, Field Crop \\ Research Institute, ARC. Egypt
}

\begin{abstract}
Two field experiments were conducted at the Experimental Farm of El-Sirw Agricultural Research Station, Dammietta Governorate, Egypt, in 2007 and 2008 seasons, to study the effect of phosphorus rate $\left(0,18,36\right.$, and $\left.54 \mathrm{~kg} \mathrm{P}_{2} \mathrm{O}_{5} / \mathrm{ha}\right)$ and Zinc rate $\left(0,12,24\right.$ and $\left.36 \mathrm{~kg} \mathrm{ZnSO}_{4} / \mathrm{ha}\right)$ on productivity of some rice cultivars (Giza177, Giza 178 and Sakha104 as inbred cultivars and hybrid cultivar SK2034H) under saline soil conditions.

The hybrid rice cultivar SK2034H was superior to other cultivars in leaf area index, dry matter production $\left(\mathrm{g} / \mathrm{m}^{2}\right)$, number of tillers $/ \mathrm{m}^{2}$, number of panicles $/ \mathrm{m}^{2}$, panicle length, number of filled grains/panicle, grain yield, straw yield, harvest index and nitrogen, phosphorus and protein content of grains in both seasons and plant height only in the second season. However, Giza 177 gave the heaviest 1000-grain weight.

Increasing phosphorus rate from 0 to $36 \mathrm{~kg} \mathrm{P}_{2} \mathrm{O}_{5} /$ ha significantly increased leaf area index, number of tillers $/ \mathrm{m}^{2}$, number of panicles $/ \mathrm{m}^{2}$, panicle length, panicle weight, number of filled grains/panicle, grain yield and harvest index in the two seasons. However, the highest dry weight $/ \mathrm{m}^{2}, 1000$-grain weight, straw yield and $\mathrm{N}, \mathrm{P}$ and crude protein contents of grains was obtained from application of $54 \mathrm{~kg} \mathrm{P} \mathrm{P}_{5} / \mathrm{ha}$. There were no significant differences in plant height among phosphorus rates in the two seasons of study.

Increasing zinc rate from 0 to $36 \mathrm{~kg} \mathrm{ZnSO}_{4} / \mathrm{ha}$ significantly increased leaf area index, dry matter production, panicle length, panicle weight, 1000-grain weight, grain yield, straw yield, harvest index and $\mathrm{N}$ and crude protein contents of grains. The inverse was true in unfilled grains \% and phosphorus content of grains. Application of 24 and $36 \mathrm{~kg} \mathrm{ZnSO} 4 / \mathrm{ha}$, being insignificant, increased number of tillers $/ \mathrm{m}^{2}$, number of panicles $/ \mathrm{m}^{2}$ and number of filled grains/panicle compared with control (without zinc fertilizer). Zinc fertilizer rate had no significant effect on plant height in both seasons.

All the first and second order interaction had significant effects on grain yield/ha. The maximum grain yield was obtained from the hybrid cultivar SK2034H fertilized by $54 \mathrm{~kg} \mathrm{P} \mathrm{P}_{5}+36 \mathrm{~kg} \mathrm{ZnSO} 4 /$ ha or $36 \mathrm{~kg} \mathrm{P} \mathrm{O}_{5}+24 \mathrm{~kg} \mathrm{ZnSO} / /$ ha in the two seasons. The highest grain yield of Giza 178 and Sakha104 were obtained by application of $36 \mathrm{~kg} \mathrm{P} 2 \mathrm{O}_{5}$ and $36 \mathrm{~kg} \mathrm{ZnSO} 4 / \mathrm{ha}$.

It can be concluded that sowing SK2034H rice cultivar and application phosphorus fertilizer at the rate of $54 \mathrm{~kg} \mathrm{P}_{2} \mathrm{O}_{5} /$ ha and Zinc fertilizer at the rate of 24 or $36 \mathrm{~kg} \mathrm{ZnSO} 4$ could be recommended to produce optimum grain yield per unit area under saline soil condition.
\end{abstract}

\section{INTRODUCTION}

Rice ability to grow on saline soils is justified by world practice. Many researchers consider rice to be a crop with medium salt resistance. But since water layer reduces salt concentration, plant growth is not inhibited. Soil 
salinity causes adverse effects on different physiological processes, which are responsible for reduction of growth of plants (Ashraf, 2004 and Munns et al, 2006). So, increasing salt tolerance of crops is necessary to sustain food production in different saline regions (Pitman and Lauchli, 2002). Selection of the suitable rice variety is the first prerequisite for a good yield. The salt tolerance of rice variety is a key factor influencing crop yield and quality under saline soils conditions. Zayed et al. (2006) recorded varietal difference in growth, grain yield and its components under saline soil conditions. Gautam (2004) obtained a significantly better growth performance from hybrids than conventional varieties, particularly in LAl, dry mater (at heading and grain filling) plant height and panicle length. In addition, Gautam (2004) and Abou Khalifa (2005) emphasized superiority of rice hybrid over inbred ones in panicles number/plant, filled grains/panicle, fertility percentage, panicle weight, 1000-grain weight, harvest index as well as straw and grain yields. On the other hand, Zayed et al. (2007), Alam et al. (2009) and Zayed et al. (2010) recognized variation between inbred rice and hybrid varieties regarding growth, grain yields and its attributing characteristics under normal and saline soils.

Sodic soils have high concentrations of free carbonate and bicarbonate and excess of sodium on the exchangeable site of clay particles. They are deficient in nitrogen, phosphorus and zinc. Supplementary phosphorus has a role in alleviation of the adverse effects of high salinity on whole plant biomass for a variety of crop plants (Kaya et al., 2003). Wilson et al. (1999) stated that phosphorous uptake and content was decreased as $\mathrm{pH}$ value increased beyond 7 and phosphorous application significantly increased rice grain yield and P tissue content. Panda et al. (1995) and Heluf and Seyoum (2006) reported that increased dry matter production including grain yield and yield attributing characters of rice (number of panicles $/ \mathrm{m}^{2}$, number of spikeletspanicle ${ }^{-1}$, panicle length, dry matter accumulation, plant height and straw yield) due to $P$ uptake in response to external supply of $P$ fertilizers. Ali and Ansari (2006) indicated that under high sodicity, increasing phosphorous level significantly increased dry mater, LAl, chlorophyll content, panicles number, filled grains, panicle weight grain and straw yields as result of increasing rice salt tolerance and reducing $\mathrm{Na}$ uptake. Alam et al. (2009) reported that rice growth parameters, grain yield, straw yield and harvest index as well as yield attributing characteristics significantly increased by phosphorous application up to $72 \mathrm{~kg} \mathrm{P}_{2} \mathrm{O}_{5} \mathrm{ha}^{-1}$, and beyond this level these traits started to decrease.

Zinc plays an important role in many biochemical reactions within different plants. Zinc modifies and/or regulates the activity of carbonic anhydrase and enzyme that regulates the conversion of carbon dioxide to reactive bicarbonate species for fixation to carbohydrates in these plants. Zinc is also a part of several other enzymes such as superoxide dismutase and catalase, which prevents oxidative stress in plant cells. Shehata et al (2009), under saline soil condition, found that zinc fertilizer had a positive effect on rice growth traits,i.e. dry matter production, leaf area index and yield attributes, i.e. panicle number/hill, plant height, panicle length, panicle weight, filled grains/panicle, 1000-grain weight, straw and grain yields. Also, Bharat 
(2006), under saline sodice conditions, recognized that zinc application significantly increased grain and straw yields and harvest index. Many previous investigators reported that increasing zinc rate increased grain yield and its attributes (Ghose et al,1999; Rao and Shukla, 1999; Zia et al, 2000; Hussain, 2004; Tariq et al., 2007 and Khan et al,2009). Malavolta et al (2002) found that foliar spraying with zinc solution increased rice grain yield.

Therefore, The main objective of this attempt is to select the best salt tolerant cultivar and its suitable fertilizer (phosphorous and zinc rates), which could produce satisfactory yield under saline soil conditions.

\section{MATERIALS AND METHODS}

Two field experiments were conducted at the Experimental Farm of El-Sirw Agricultural Research Station, Dammietta Governorate, Egypt, in 2007 and 2008 seasons, to study the effect of phosphorus and Zinc fertilizer on growth, yield, yield components and some grain quality of some rice cultivars under saline soil conditions. The previous crop was Egyptian clover (Trifolium alexandrinum, L) in both seasons. Representative soil samples were taken from each site at the depth of $0-30 \mathrm{~cm}$ from the soil surface. Samples were air-dried then ground to pass through a two $\mathrm{mm}$ sieve and well mixed. The procedure of soil analysis followed the methods of Black et al. (1965). Results of chemical analysis in both seasons are shown in Table 1. Phosphorus fertilizer in the form of calcium super phosphate $\left(15.5 \% \mathrm{P}_{2} \mathrm{O}_{5}\right)$ were applied at the four rates of $0,18,36$, and $54 \mathrm{KgP}_{2} \mathrm{O}_{5} / \mathrm{ha}$ as basal application on the dry soil and incorporated with soil during land preparation. The experimental soils were divided into four parts before plowing. Each part was located to each phosphorus rate as independent experiment. The experimental design was a split-plot with three replicates in each phosphorus rate in both seasons. Main plots were assigned to rice cultivars, sub plots to zinc rate.

Table 1: Some chemical properties of the soil in the experimental sites

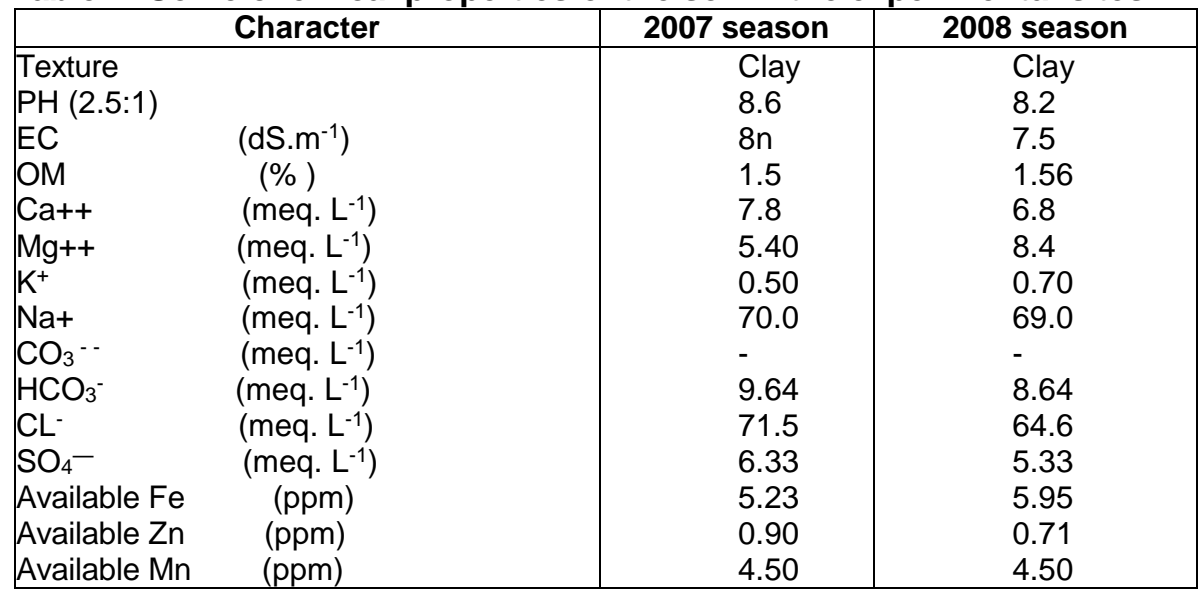


Gharib, H. S. et al.

Four rice cultivars consisted of three inbred cultivars, namely Giza177, Giza 178 and Sakha104 as well as one hybrid cultivar, namely Sk2034H were used. Zinc sulfate was applied with the four rates of $0,12,24$ and $36 \mathrm{~kg}$ $\mathrm{ZnSO}_{4} / \mathrm{ha}$ after wet leveling. A combined analysis was used among phosphorus rates in each season. The plot size was $10.8 \mathrm{~m}^{2}(3 \times 3.6 \mathrm{~m})$ in all experiments. In each plot, an area of $2.16 \mathrm{~m}^{2}(0.6 \times 3.6 \mathrm{~m})$ was devoted for plant growth sampling and $8.64 \mathrm{~m}^{2}(2.4 \times 3.6 \mathrm{~m})$ for determining grain yield and its attributes. Every plot consists of 15 rows and the distance between the hills and the rows was $20 \times 20 \mathrm{~cm}$ for Giza 178, Sakha104 and SK2034H cultivars. However, every plot consists of 20 rows and the distance between the hills and rows was $15 \times 15 \mathrm{~cm}$ for Giza 177 cultivar.

The seed of each inbred rice cultivar at the rate of $144 \mathrm{~kg} \mathrm{seed} / \mathrm{ha}$ and hybrid cultivar at the rate of $35 \mathrm{~kg} \mathrm{seed} /$ ha were soaked in water for 36 hours then drained and incubated for 48 hours to hasten early germination. Pre-germinated seeds were uniformly broadcast in the nursery on May $15^{\text {th }}$, in 2007 and 2008 seasons. The zinc and phosphorus fertilizers did not apply in the nursery. The other cultural practices were applied as recommended. The permanent field was identified and well prepared. Seedlings were carefully pulled form nursery after 30 days and transferred to the permanent field. Seedlings were handling transplanted in hills at the rate of 3-4 seedlings/hill. At the spacing of $20 \times 20 \mathrm{~cm}$ between hills and rows for all cultivar except the cultivar Giza177 where the spacing were $15 X 15 \mathrm{~cm}$. Nitrogen in from of urea $(46 \% \mathrm{~N})$ at rate of $165 \mathrm{~kg} / \mathrm{ha}$ was applied in three equal doses. The first dose was applied and ported in the dry soil before flooding, the second and third at 15 and 35 days after transplanting. The other usual agricultural practices of growing rice were performed as the recommendations of Ministry of Agriculture and Land Reclamation. Plant sample (five hills each) were taken randomly from each plot at heading to estimate the plant height $(\mathrm{cm})$, leaf area, dry matter $\mathrm{g} / \mathrm{m}^{2}$ and number of tillers $/ \mathrm{m}^{2}$. Leaf area (blade area) was measured by portable area meter (Model LI-3000A). Then LAl was calculated (dividing Leaf area per hill /ground area/hill). At harvesting number of panicles $/ \mathrm{m}^{2}$ were counted. Ten panicles were collected randomly to estimate the panicle weight, panicle length, number of filled grains and unfilled grains/panicle and 1000-grain weight. The total weight of both grain and straw was recorded. The weight of grains was adjusted to $14 \%$ moisture content. Samples were taken from grain and straw at harvest to determine $\mathrm{N}$ and $\mathrm{P}$ contents. All samples were oven dried to a constant weight at $70^{\circ} \mathrm{C}$, then ground to powder and digested according the method of Chapman and Pratt (1961). Total N was determined by MicroKjeldahl method (Blak et al.,1965) and $\mathrm{P}$ calorimetrically by ascorbic acid according to Watanabe and Olsen (1965).Nitrogen content in rice grains was multiplied by factor of 5.95 to estimate the crude protein content in rice grains.

The analysis of variance was carried out as a combined analysis for the four sowing dates in each season according to Gomez and Gomez (1984). Treatment means were compared by Duncan's Multiple Range Test (Duncan, 1955). All statistical analysis was performed using analysis of variance technique by means of "MSTATC" computer software package. 


\section{RESULTS AND DISCUSSION}

\section{A- Growth:}

Leaf area index (LAl), plant height, dry matter accumulation and tillers number of some rice cultivars at heading as affected by phosphors, zinc rates and their interaction in 2007 and 2008 seasons are presented in Table 2.

\section{Rice cultivars performance:}

Rice cultivars varied significantly in all mentioned growth traits in both seasons, except plant height in the first season. The hybrid rice cultivar SK2034H was significantly superior to the other cultivars in LAl, dry weight $/ \mathrm{m}^{2}$ and tillers number $/ \mathrm{m}^{2}$ in the two seasons. The minimum values of the mentioned traits were recorded by the salt sensitive cultivar Giza177 in both seasons. Giza 178 came in the second order in this respect. The superiority of SK2034H cultivar could be attributed to more number of tillers and leaves resulted in large photosynthetic area (leaf area), which resulted in more photosynthetic production and consequently increased dry matter accumulation. The varietal differences in LAl are reflected different genetic make up. The current findings are in agreement with those reported by Alam et al (2009) and Zayed et al (2010), who revealed that hybrid rice surpassed inbred rice verities in LAl, dry matter and number of tillers.

\section{Effect of phosphorus rate:}

Application of phosphorus fertilizer resulted in a significant increase in LAl, dry weight $/ \mathrm{m}^{2}$ and number of tillers $/ \mathrm{m}^{2}$ compared with control (without phosphorus fertilizer). However, phosphorus rate had no significant effect on plant height. LAI was significantly increased by increasing phosphors rate from 0 to $36 \mathrm{~kg} \mathrm{P}_{2} \mathrm{O}_{5} / \mathrm{ha}$ and then it was decreased in both seasons.

Increasing phosphorus rate from 0 up to $54 \mathrm{~kg} \mathrm{P}_{2} \mathrm{O}_{5} /$ ha gradually increased dry matter production in both seasons. The relative ranking of phosphorus rates for number of tillers was inconsistent in the two seasons. Plants received 36 or $54 \mathrm{~kg} \mathrm{P}_{2} \mathrm{O}_{5} / \mathrm{ha}$ were among those having great number of tillers $/ \mathrm{m}^{2}$ in both seasons. No significant difference in number of tillers $/ \mathrm{m}^{2}$ was observed between the two higher rates of phosphorus in the two seasons. Phosphorus application ameliorated the unfavorable effect of salinity resulted in improving plant growth and in turn increased tillers numbers, LAl and dry matter accumulation. Also, phosphorus application might be increasing phosphorus availability and subsequently increased its uptake and its content in rice plants leading to more ATP formation, that is the main stare for energy in plant and might encourage rice growth, metabolism, photosynthesis and nucleic acid resulted in high efficiency of dry matter production. The results are in agreement with those reported by Suriya-arunroj et al (2000), Kumar and Singh (2001), Biswas and Dravid (2001), Hood (2002), Ali et al (2004), Bharat (2006) and Zayed et al (2010). 
Gharib, H. S. et al.

Table 2: Leaf area index, dry matter accumulation, plant height and tillers number of some rice cultivars as affected by phosphors, zinc rates and their interaction in 2007 and 2008 seasons.

\begin{tabular}{|c|c|c|c|c|c|c|c|c|}
\hline \multirow{2}{*}{ Factor } & \multicolumn{2}{|c|}{ Leaf area index } & \multicolumn{2}{|c|}{ Dry weight $\left(\mathrm{g} / \mathrm{m}^{2}\right)$} & \multicolumn{2}{|c|}{ Plant height (cm) } & \multicolumn{2}{|c|}{ Tillers (No. $\mathbf{m}^{-2}$ ) } \\
\hline & 2007 & 2008 & 2007 & 2008 & 2007 & 2008 & 2007 & 2008 \\
\hline Cultivar (C): & & & & & & & & \\
\hline Giza 177 & $2.79 d$ & $2.72 d$ & $525.4 d$ & $513.1 \mathrm{~b}$ & 91.23 & $81.66 \mathrm{~b}$ & $342 d$ & $335 c$ \\
\hline Giza 178 & $4.36 \mathrm{~b}$ & $4.23 \mathrm{~b}$ & $792.8 \mathrm{~b}$ & $783.1 \mathrm{a}$ & 92.13 & $85.61 \mathrm{ab}$ & $402 \mathrm{~b}$ & $418 b$ \\
\hline Sakha104 & $3.98 \mathrm{c}$ & $3.86 \mathrm{c}$ & $617.1 \mathrm{c}$ & $602.9 \mathrm{~b}$ & 94.13 & $86.99 a$ & $370 \mathrm{c}$ & $409 \mathrm{~b}$ \\
\hline $\begin{array}{l}\text { SK2034H } \\
\text { F test }\end{array}$ & $\underset{*}{5.38 a}$ & $\underset{* *}{5.32 a}$ & $\underset{\star *}{847.3 a}$ & $\underset{* *}{835.2 a}$ & $\begin{array}{l}90.93 \\
\text { NS }\end{array}$ & $\underset{*}{89.60 a}$ & $\underset{* *}{451 \mathrm{a}}$ & 457 a \\
\hline $\mathrm{Kg} \mathrm{P}_{2} \mathrm{O}_{5} / \mathrm{ha}(\mathrm{P}):$ & & & & & & & & \\
\hline 0 & $3.60 \mathrm{~d}$ & $3.50 d$ & $633.0 \mathrm{~d}$ & $604.0 \mathrm{~d}$ & 91.1 & 85.6 & $365 c$ & $368 c$ \\
\hline 18 & $4.11 \mathrm{c}$ & $4.01 \mathrm{c}$ & $679.3 c$ & $650.3 c$ & 92.9 & 85.78 & $384 b$ & $399 \mathrm{~b}$ \\
\hline 36 & $4.55 a$ & $4.45 a$ & $724.1 \mathrm{~b}$ & $711.9 b$ & 92.55 & 86.09 & $412 \mathrm{a}$ & $432 \mathrm{a}$ \\
\hline 54 & $4.26 b$ & $4.18 b$ & $746.2 a$ & 768.0a & 91.85 & 86.4 & $414 \mathrm{a}$ & $421 a b$ \\
\hline$F$ test & & $* *$ & & & & & & \\
\hline $\mathrm{Kg} \mathrm{Zn} \mathrm{SO}_{4} / \mathrm{ha} \mathrm{(Z):}$ & & & & & & & & \\
\hline 0 & $3.46 \mathrm{~d}$ & $3.50 \mathrm{~d}$ & $633.0 \mathrm{~d}$ & $615.8 d$ & 91.1 & 82.79 & $361 \mathrm{c}$ & $358 c$ \\
\hline 12 & $3.95 c$ & $3.77 \mathrm{c}$ & $679.3 c$ & $665.8 \mathrm{c}$ & 92.9 & 86.50 & $388 \mathrm{~b}$ & $403 \mathrm{~b}$ \\
\hline 24 & $4.46 \mathrm{~b}$ & $4.30 \mathrm{~b}$ & $724.1 \mathrm{~b}$ & $714.9 \mathrm{~b}$ & 92.55 & 87.57 & $408 \mathrm{a}$ & $430 a$ \\
\hline 36 & $4.65 a$ & $4.56 \mathrm{a}$ & $746.2 a$ & $737.9 a$ & 91.85 & 86.99 & $407 \mathrm{a}$ & $428 \mathrm{a}$ \\
\hline F test & & $* *$ & $\star *$ & & NS & NS & $* *$ & $\star *$ \\
\hline Interaction: & & & & & & & & \\
\hline & * & NS & NS & NS & NS & NS & NS & NS \\
\hline & ** & NS & NS & NS & NS & NS & NS & NS \\
\hline P X Z & ** & NS & NS & NS & NS & NS & NS & NS \\
\hline$P \times Z \times C$ & NS & NS & NS & NS & NS & NS & NS & NS \\
\hline
\end{tabular}

${ }^{*},{ }^{* *}$ and NS indicate $P<0.05, P<0.01$ and not significant, respectively. Means of each factor designated by the same latter are not significantly different at $5 \%$ level using Duncan's MRT.

\section{Effect of zinc rate:}

LAl, dry weight $/ \mathrm{m}^{2}$ and number of tillers $/ \mathrm{m}^{2}$ were substantially increased by application of zinc fertilizer compared with control (without zinc fertilizer) in the two seasons. Plant height was not significantly affected by zinc rate in both seasons. Data in Table 2 reveal that progressive significant increase in LAl and dry weight $/ \mathrm{m}^{2}$ were recorded with each increment of applied zinc.

Application of zinc with the rates of 24 or $36 \mathrm{~kg} \mathrm{ZnSO} / /$ ha produced greater number of tillers than the rate of $12 \mathrm{~kg} \mathrm{ZnSO} / /$ ha in the two seasons. There was no significant difference between the two higher rates of 24 or 36 $\mathrm{kg} \mathrm{ZnSO} / \mathrm{ha}$ in number of tillers/ $\mathrm{m}^{2}$ in both seasons. Results indicate that zinc supply had a controlling influence on LAl, primarily through its effect on tillers number and thus leaf production and expansion. Zinc has a vital role in improve rice growth, where it works as co-enzyme and as activators and enhanced amino acid formation, subsequently increased photosynthesis leading to high dry matter production. The present results are in a good harmony with those claimed by Coutinho et al (1992), Biswas and Dravid (2001), Hood (2002) and Shehata et al(2009). 
4. Effect of interaction:

All the first order interaction had a significant effect on LAl only in the first season. However, none of the interaction had a significant effect on dry weight $/ \mathrm{m}^{2}$, plant height and number of tillers $/ \mathrm{m}^{2}$ in both seasons.

\section{B. Yield and its attributes:}

Number of panicle $/ \mathrm{m}^{2}$, panicle length, panicle weight, number of filled grains/panicle, unfilled grains\%, 1000-grain weight, grain yield (t/ha), straw yield ( $\mathrm{t} / \mathrm{ha}$ ) and harvest index of some rice cultivars as affected by phosphors and zinc rates and their interaction are presented in Tables 3, 4 and 5.

\section{Rice cultivars performance:}

Rice cultivars exhibited significant differences in all yield attributes in both seasons. The hybrid rice cultivar SK2034H was significantly superior to the other cultivars in panicle number $/ \mathrm{m}^{2}$, panicle length, panicle weight, number of filled grains/panicle, grain yield (t/ha), straw yield (t/ha) and harvest index. Giza 178 came in the second order after SK2034H in the most of these traits. However, the cultivar Giza177 was inferior to all other cultivars in these respects. The inverse was true in 1000-grain weight and unfilled grains \%, where Giza177 recorded the highest values in the two traits in both seasons.

Table 3: Number of panicles, panicle length and panicle weight of some rice cultivars as affected by phosphors and zinc rates and their interaction in 2007 and 2008 seasons.

\begin{tabular}{|c|c|c|c|c|c|c|}
\hline \multirow{2}{*}{ Factor } & \multicolumn{2}{|c|}{ Panicles ( No. $\mathrm{m}^{-2}$ ) } & \multicolumn{2}{|c|}{ Panicle length(cm) } & \multicolumn{2}{|c|}{ Panicle weight (g) } \\
\hline & 2007 & 2008 & 2007 & 2008 & 2007 & 2008 \\
\hline Cultivar (C): & & & & & & \\
\hline Giza 177 & $303 \mathrm{~d}$ & $294 \mathrm{c}$ & $19.48 c$ & $19.28 d$ & $2.24 c$ & $2.38 c$ \\
\hline Giza 178 & $359 \mathrm{~b}$ & $371 \mathrm{~b}$ & $20.29 b$ & $20.41 b$ & $2.71 b$ & $2.78 b$ \\
\hline Sakha104 & $341 \mathrm{c}$ & $369 \mathrm{~b}$ & $19.85 c$ & $19.95 c$ & $2.63 b$ & $2.74 b$ \\
\hline SK2034H & $414 \mathrm{a}$ & $424 \mathrm{a}$ & $21.00 \mathrm{a}$ & $20.51 \mathrm{a}$ & $3.11 \mathrm{a}$ & $3.23 a$ \\
\hline F test & ** & ** & $\star *$ & $\star \star$ & $* *$ & $* *$ \\
\hline $\mathrm{Kg} \mathrm{P}_{2} \mathrm{O}_{5} / \mathrm{ha}(\mathrm{P}):$ & & & & & & \\
\hline 0 & $303 c$ & $329 \mathrm{c}$ & $19.41 d$ & $19.52 d$ & 2.33d & $2.46 c$ \\
\hline 18 & $348 \mathrm{~b}$ & $359 \mathrm{~b}$ & $20.03 c$ & $19.99 c$ & $2.65 c$ & $2.75 \mathrm{~b}$ \\
\hline 36 & $386 \mathrm{a}$ & $391 \mathrm{a}$ & $20.78 a$ & $20.59 a$ & $2.94 \mathrm{a}$ & $3.00 \mathrm{a}$ \\
\hline 54 & $381 \mathrm{a}$ & $378 a b$ & $20.40 \mathrm{~b}$ & $20.41 b$ & $2.76 b$ & $2.92 a$ \\
\hline$F$ test & ** & ** & $\star *$ & $\star *$ & * & $* *$ \\
\hline $\mathrm{Kg} \mathrm{Zn} \mathrm{SO}_{4} / \mathrm{ha} \mathrm{(Z):}$ & & & & & & \\
\hline 0 & $325 \mathrm{~b}$ & $333 c$ & $19.16 d$ & $19.35 d$ & $2.35 c$ & $2.45 c$ \\
\hline 12 & $353 a$ & $356 \mathrm{~b}$ & $20.00 \mathrm{c}$ & $19.92 c$ & $2.63 b$ & $2.77 \mathrm{~b}$ \\
\hline 24 & $375 a$ & $386 a$ & $20.54 b$ & $20.44 b$ & $2.85 a$ & $2.95 a$ \\
\hline 36 & $365 a$ & $382 a b$ & $20.93 a$ & $20.81 a$ & $2.86 \mathrm{a}$ & $2.96 a$ \\
\hline F test & ** & & $* *$ & * & $* *$ & $* *$ \\
\hline Interaction: & & & & & & \\
\hline $\mathrm{C} \times \mathrm{P}$ & ** & ** & NS & ** & ** & ** \\
\hline$C \times Z$ & * & ** & NS & ** & ** & ** \\
\hline$P \times Z$ & ** & * & $\star *$ & $* *$ & * & * \\
\hline$P \times Z \times C$ & * & ** & NS & NS & NS & NS \\
\hline
\end{tabular}

** and NS indicate $P<0.05, P<0.01$ and not significant, respectively. Means of each factor designated by the same latter are not significantly different at $5 \%$ level using Duncan's MRT. 
Gharib, H. S. et al.

Obtained results suggest the importance of panicles number $/ \mathrm{m}^{2}$ and filled grains number/panicle in determining the magnitude of increase or decrease in grain yield. The superiority of SK2034H cultivar in grain yield was due to its highest number of panicles $/ \mathrm{m}^{2}$ and greatest number of filled grains/panicle. Gautam (2004), Singh et al. (2004), Abou Khalifa (2005), Zayed et al (2006), Zayed et al (2007), Alam et al (2009) and Zayed et al (2010) indicated that hybrid rice surpassed inbred rice in grain yield, number of panicles and number of filled grains/panicle.

\section{Effect of phosphorus rate:}

Application of phosphorus fertilizer resulted in a significant increase in grain and straw yields as well as all yield attributes compared with control (without phosphorus) in both seasons. Increasing phosphorus rate from 0 up to $36 \mathrm{~kg} \mathrm{P} \mathrm{O}_{5} / \mathrm{ha}$ gradually increased number of panicles $/ \mathrm{m}^{2}$, panicle length, panicle weight, number of filled grains/panicle, grain yield and harvest index in both seasons. The inverse was true in unfilled grains \%. However, adding $54 \mathrm{~kg} \mathrm{P}_{2} \mathrm{O}_{5} /$ ha produced heavier 1000-grain weight and straw yield. There was no significant difference in number of panicles $/ \mathrm{m}^{2}, 1000$-grain weight and straw yield between the two higher rates of 36 or $54 \mathrm{~kg} \mathrm{P}_{2} \mathrm{O}_{5} / \mathrm{ha}$ in both seasons.

Table 4: Number of filled grains/panicle, unfilled grains \% and 1000grain weight of some rice cultivars as affected by phosphors and zinc rates and their interaction in 2007 and 2008 seasons

\begin{tabular}{|c|c|c|c|c|c|c|}
\hline \multirow[t]{2}{*}{ Factor } & \multicolumn{2}{|c|}{$\begin{array}{l}\text { Filled grains } \\
\text { (No./panicle) }\end{array}$} & \multicolumn{2}{|c|}{$\begin{array}{c}\text { Unfilled grains } \\
(\%)\end{array}$} & \multicolumn{2}{|c|}{1000 - grain weight $(\mathrm{g})$} \\
\hline & 2007 & 2008 & 2007 & 2008 & 2007 & 2008 \\
\hline Cultivar (C): & & & & & & \\
\hline Giza 177 & $107.6 c$ & $92.9 c$ & $6.17 a$ & $5.15 a$ & $24.29 a$ & $24.98 a$ \\
\hline Giza 178 & $128.4 b$ & $145.8 \mathrm{a}$ & $4.78 b$ & $2.64 \mathrm{c}$ & 18.81d & $18.74 \mathrm{c}$ \\
\hline Sakha104 & $123.4 b$ & $105.5 b$ & $5.15 b$ & $4.44 b$ & $23.41 b$ & $25.06 a$ \\
\hline SK2034H & $136.5 a$ & $146.2 \mathrm{a}$ & $5.11 b$ & $3.87 b$ & $22.58 c$ & $21.17 b$ \\
\hline F test & ** & ** & ** & $* *$ & ** & ** \\
\hline$\underline{\mathrm{Kg} \mathrm{P}} \mathrm{P}_{2} \underline{\mathrm{O}}_{5} / \mathrm{ha}(\mathrm{P}):$ & & & & & & \\
\hline 0 & $119.8 b$ & $115.7 \mathrm{c}$ & $7.55 a$ & $5.31 \mathrm{a}$ & $21.83 b$ & $21.29 \mathrm{~b}$ \\
\hline 18 & $124.3 a$ & $119.7 b$ & $5.44 b$ & $4.28 b$ & $22.12 b$ & $22.43 \mathrm{~b}$ \\
\hline 36 & $126.7 a$ & $127.7 a$ & $3.89 c$ & $3.02 \mathrm{c}$ & $22.14 b$ & $22.78 a b$ \\
\hline 54 & $125.2 \mathrm{a}$ & $127.4 \mathrm{a}$ & $4.32 \mathrm{c}$ & $3.49 c$ & $22.98 a$ & $23.44 \mathrm{a}$ \\
\hline F test & ** & ** & $\star *$ & $* *$ & ** & ** \\
\hline $\mathrm{Kg} \mathrm{Zn} \mathrm{SO}_{4} / \mathrm{ha} \mathrm{(Z):}$ & & & & & & \\
\hline 0 & $115.3 c$ & $114.9 c$ & $6.51 \mathrm{a}$ & $5.50 a$ & $21.46 b$ & $21.84 \mathrm{c}$ \\
\hline 12 & $125.0 \mathrm{~b}$ & 123.0b & $5.52 b$ & $3.95 b$ & $22.34 a$ & $22.34 \mathrm{a}$ \\
\hline 24 & $127.9 a$ & 125.6ab & $4.64 c$ & $3.62 b$ & $22.58 a$ & $22.85 \mathrm{a}$ \\
\hline 36 & $127.6 a$ & $126.8 a$ & $4.48 c$ & $3.03 c$ & $22.69 a$ & $22.92 \mathrm{a}$ \\
\hline$F$ test & $\star \star *$ & * & ** & $\star *$ & ** & ** \\
\hline Interaction: & & & & & & \\
\hline $\mathrm{CXP}$ & * & ** & * & NS & ** & ** \\
\hline$C \times Z$ & ** & * & * & $* *$ & ** & ** \\
\hline$P \times Z$ & ** & * & * & $* *$ & * & * \\
\hline$P \times Z \times C$ & * & ** & NS & ** & NS & NS \\
\hline
\end{tabular}

${ }^{\star \star}$ and NS indicate $P<0.05, P<0.01$ and not significant, respectively. Means of each factor designated by the same latter are not significantly different at $5 \%$ level using Duncan's MRT. 
The trend of most attributes is similar to those of dry matter accumulation, leaf area index and number of tillers $/ \mathrm{m}^{2}$ and similar discussion could be cited. Application of $36 \mathrm{~kg} \mathrm{P} \mathrm{O}_{5} / \mathrm{ha}$ increased grain yield through the increase in number of panicles $/ \mathrm{m}^{2}$, panicle weight, the number of filled grains/panicle and 1000 -grain weight. The results are in agreement with those reported by Biswas and Dravid (2001), Ibrahim (2001), Kumar and Singh (2001), Hood (2002), Bharat (2006), Alam et al(2009) and Zayed et al (2010).

\section{Effect of zinc rate:}

Zinc application had a positive effect on yield and all yield attributes, except unfilled grains \% in both seasons. Plants received $36 \mathrm{~kg} \mathrm{ZnSO} / /$ ha produced the highest number of panicles $/ \mathrm{m}^{2}$, panicle length, panicle weight, number of filled grains/panicle, 1000-grain weight, grain yield, straw yield and harvest index, while control plants produced the lowest one. Application of $24 \mathrm{~kg}$ $\mathrm{ZnSO}_{4} / \mathrm{ha}$ was statistically at par with $36 \mathrm{~kg} \mathrm{ZnSO} / \mathrm{ha}$ in number of panicles/ $\mathrm{m}^{2}$, number of filled grains/panicle and 1000-grain weight in both seasons.

Table 5: Grain yield, straw yield and harvest index of some rice cultivars as affected by phosphors and zinc rates and their interaction in 2007 and 2008 seasons

\begin{tabular}{|c|c|c|c|c|c|c|}
\hline \multirow{2}{*}{ Factor } & \multicolumn{2}{|c|}{ Grain yield (t/ha) } & \multicolumn{2}{|c|}{ Straw yield (t/ha) } & \multicolumn{2}{|c|}{ Harvest index } \\
\hline & 2007 & 2008 & 2007 & 2008 & 2007 & 2008 \\
\hline \multicolumn{7}{|l|}{ Cultivar (C): } \\
\hline Giza 177 & $4.51 d$ & $5.03 d$ & $9.29 d$ & $9.57 c$ & $0.32 c$ & $0.34 \mathrm{c}$ \\
\hline Giza 178 & $6.38 b$ & $6.82 b$ & $10.90 \mathrm{~b}$ & $10.89 b$ & $0.36 b$ & $0.38 b$ \\
\hline Sakha104 & $5.17 c$ & $5.60 c$ & $10.44 c$ & $10.70 \mathrm{~b}$ & $0.32 c$ & $0.34 c$ \\
\hline SK2034H & 7.00a & 7.66a & $11.29 a$ & $11.26 a$ & $0.38 a$ & $0.40 \mathrm{a}$ \\
\hline $\mathrm{F}$ test & & & & & & \\
\hline \multicolumn{7}{|l|}{$\mathrm{Kg} \mathrm{P}_{2} \mathrm{O}_{5} / \mathrm{ha}(\mathrm{P}):$} \\
\hline 0 & $4.89 d$ & $5.28 c$ & $9.66 c$ & $9.97 \mathrm{c}$ & $0.33 b$ & $0.35 b$ \\
\hline 18 & $5.30 c$ & $5.86 b$ & $10.35 b$ & $10.43 b$ & $0.33 c$ & $0.36 b$ \\
\hline 36 & $6.65 a$ & $7.02 \mathrm{a}$ & $11.03 a$ & $11.03 a$ & $0.37 a$ & $0.39 a$ \\
\hline 54 & $6.31 b$ & $6.94 a$ & $10.94 a$ & $10.99 a$ & $0.35 b$ & $0.38 a$ \\
\hline F test & $* *$ & $* *$ & ** & * & ** & ** \\
\hline \multicolumn{7}{|l|}{$\mathrm{Kg} \mathrm{Zn} \mathrm{SO}_{4} / \mathrm{ha} \mathrm{(Z):}$} \\
\hline 0 & $4.87 \mathrm{c}$ & $5.33 d$ & $9.51 d$ & $9.81 \mathrm{c}$ & $0.33 c$ & $0.35 d$ \\
\hline 12 & $5.50 b$ & $5.98 c$ & $10.36 c$ & $10.45 b$ & $0.34 b$ & $0.36 c$ \\
\hline 24 & $6.24 a$ & $6.65 b$ & $10.93 b$ & $10.99 a$ & $0.36 a$ & $0.37 b$ \\
\hline 36 & $6.45 a$ & 7.15a & $11.18 a$ & $11.17 a$ & $0.36 \mathrm{a}$ & $0.39 a$ \\
\hline$F$ test & $\star \star$ & ** & ** & $\star \star$ & ** & \\
\hline \multicolumn{7}{|l|}{ Interaction: } \\
\hline $\mathrm{C} \times \mathrm{P}$ & ** & ** & ** & ** & ** & ** \\
\hline$C \times Z$ & ** & ** & ** & ** & ** & ** \\
\hline$P \times Z$ & * & ** & $* *$ & $* *$ & $* *$ & $* *$ \\
\hline $\mathrm{P} \times \mathrm{Z} \times \mathrm{C}$ & * & ** & NS & NS & NS & NS \\
\hline
\end{tabular}

, ${ }^{* \star}$ and NS indicate $P<0.05, P<0.01$ and not significant, respectively. Means of each factor designated by the same latter are not significantly different at $5 \%$ level using Duncan's MRT.

The effect of zinc application on yield attributes mainly due to that zinc application increased dry matter, leaf area index and number of tillers. Also, these results might be attributed to that zinc application increased the translocation of the carbohydrate and other nutrients to the grains, consequently higher harvest index were obtained. Biswas and Dravid (2001), 
Gharib, H. S. et al.

Hood (2002), Malavolta et al (2002), Bharat (2006), Tariq et al (2007) , Khan et al (2009) and Shehata et al (2009) came to the same conclusion.

4. Effect of interaction:

All the first order interactions had a significant effect on the most of yields and yield attributes. However, the second order interaction had a significant effect on number of panicles $/ \mathrm{m}^{2}$, number of filled grains/panicle, 1000 -grain weight, grain yield in the two seasons. Grain yield/ha as influenced by the first and the second order interactions in the two seasons are presented in tables 6 and7.

Table 6: Grain yield ( $t / h a)$ as affected by the interactions among rice cultivars, phosphors and zinc rates in 2007 season

\begin{tabular}{|c|c|c|c|c|c|c|}
\hline \multirow{2}{*}{$\begin{array}{c}\mathrm{P}_{2} \mathrm{O}_{5} \\
\text { (kg/ha) }\end{array}$} & \multirow{2}{*}{$\begin{array}{c}\mathrm{ZnSO}_{4} \\
\text { (Kg/ha) }\end{array}$} & \multicolumn{5}{|c|}{ Rice cultivars } \\
\hline & & Giza177 & Giza178 & Sakha104 & Sk2034H & Mean \\
\hline \multirow{10}{*}{$\begin{array}{l}0 \\
18 \\
36 \\
54 \\
\end{array}$} & & \multicolumn{4}{|c|}{ Cultivar x phosphorus } & \\
\hline & & $4.06 \mathrm{~h}$ & $5.15 \mathrm{f}$ & $4.21 \mathrm{gh}$ & $5.80 \mathrm{e}$ & \\
\hline & & $4.38 \mathrm{gh}$ & $6.13 \mathrm{de}$ & $4.47 \mathrm{gh}$ & $6.24 \mathrm{~d}$ & \\
\hline & & $5.09 \mathrm{f}$ & $6.98 \mathrm{c}$ & $6.82 \mathrm{c}$ & $7.45 \mathrm{~b}$ & \\
\hline & & $4.53 \mathrm{~g}$ & $6.98 \mathrm{c}$ & $5.20 \mathrm{f}$ & $8.52 \mathrm{a}$ & \\
\hline & & \multicolumn{4}{|c|}{ Cultivar x zinc } & \\
\hline & 0 & $3.79 \mathrm{j}$ & $5.33 \mathrm{fg}$ & $4.41 \mathrm{i}$ & $5.95 \mathrm{e}$ & \\
\hline & 12 & $4.38 \mathrm{i}$ & $5.91 \mathrm{e}$ & $4.98 \mathrm{gh}$ & $6.72 \mathrm{~d}$ & \\
\hline & 24 & $4.76 \mathrm{~h}$ & $6.99 \mathrm{~cd}$ & 5.66 ef & $7.57 \mathrm{ab}$ & \\
\hline & 36 & $5.13 \mathrm{~g}$ & $7.28 \mathrm{bc}$ & 5.64 ef & $7.766 \mathrm{a}$ & \\
\hline \multirow{6}{*}{0} & & \multicolumn{4}{|c|}{ Cultivar x phosphorus x zinc } & $\mathbf{P} \times$ zinc \\
\hline & 0 & $3.39 \mathrm{k}$ & $4.40 \mathrm{~g}-\mathrm{k}$ & $3.90 \mathrm{ijk}$ & $4.90 \mathrm{f}-\mathrm{k}$ & $4.17 \mathrm{~h}$ \\
\hline & 12 & $4.07 \mathrm{i}-\mathrm{k}$ & $4.80 \mathrm{f}-\mathrm{k}$ & $4.24 \mathrm{~h}-\mathrm{k}$ & $5.56 c-k$ & $4.67 \mathrm{~g}$ \\
\hline & 24 & $4.23 \mathrm{~h}-\mathrm{k}$ & $5.49 c-k$ & $4.24 \mathrm{~h}-\mathrm{k}$ & $6.35 \mathrm{~b}-\mathrm{k}$ & $5.08 \mathrm{f}$ \\
\hline & 36 & $4.54 \mathrm{~g}-\mathrm{k}$ & $5.86 \mathrm{c}-\mathrm{k}$ & $4.46 \mathrm{~g}-\mathrm{k}$ & 6.34 b-k & $5.30 \mathrm{f}$ \\
\hline & 0 & $3.70 \mathrm{jk}$ & $5.23 \mathrm{~d}-\mathrm{k}$ & $3.99 \mathrm{ijk}$ & $5.33 \mathrm{c}-\mathrm{k}$ & $4.56 \mathrm{~g}$ \\
\hline \multirow{4}{*}{18} & 12 & $4.12 \mathrm{ijk}$ & $5.83 c-k$ & $4.37 \mathrm{~h}-\mathrm{k}$ & $6.00 \mathrm{~b}-\mathrm{k}$ & $5.08 \mathrm{f}$ \\
\hline & 24 & $4.70 \mathrm{~g}-\mathrm{k}$ & $6.52 \mathrm{~b}-\mathrm{j}$ & $4.71 \mathrm{~g}-\mathrm{k}$ & 6.72 a-j & $5.66 \mathrm{de}$ \\
\hline & 36 & $4.98 \mathrm{f}-\mathrm{k}$ & $6.95 \mathrm{a}-\mathrm{i}$ & $4.80 \mathrm{f}-\mathrm{k}$ & $6.90 \mathrm{a}-\mathrm{i}$ & $5.91 \mathrm{~cd}$ \\
\hline & 0 & $4.03 \mathrm{ijk}$ & $6.13 \mathrm{~b}-\mathrm{k}$ & $5.20 \mathrm{~d}-\mathrm{k}$ & $6.26 \mathrm{~b}-\mathrm{k}$ & 5.41 ef \\
\hline \multirow{4}{*}{36} & 12 & $4.84 \mathrm{f}-\mathrm{k}$ & $6.50 \mathrm{~b}-\mathrm{j}$ & $6.52 \mathrm{~b}-\mathrm{j}$ & $6.95 \mathrm{a}-\mathrm{i}$ & $6.20 \mathrm{c}$ \\
\hline & 24 & 5.53 C-k & $8.15 \mathrm{a}-\mathrm{d}$ & $7.49 \mathrm{a}-\mathrm{g}$ & $8.28 \mathrm{abc}$ & $7.36 \mathrm{a}$ \\
\hline & 36 & 5.94 b-k & $8.20 \mathrm{a}-\mathrm{d}$ & 8.06 a-e & $8.32 \mathrm{abc}$ & $7.63 \mathrm{a}$ \\
\hline & 0 & 4.03 ijk & $5.49 c-k$ & $4.54 \mathrm{~g}-\mathrm{k}$ & 7.29 a-h & 5.34 ef \\
\hline \multirow{3}{*}{54} & 12 & $4.48 \mathrm{~g}-\mathrm{k}$ & $6.52 \mathrm{~b}-\mathrm{j}$ & $4.80 \mathrm{f}-\mathrm{k}$ & $8.38 \mathrm{abc}$ & $6.04 \mathrm{c}$ \\
\hline & 24 & $4.58 \mathrm{~g}-\mathrm{k}$ & 7.80 a-f & $6.22 \mathrm{~b}-\mathrm{k}$ & $8.92 a b$ & $6.88 \mathrm{~b}$ \\
\hline & 36 & 5.04 e-k & $8.12 \mathrm{a}-\mathrm{d}$ & $5.23 \mathrm{~d}-\mathrm{k}$ & $9.48 \mathrm{a}$ & $6.97 \mathrm{~b}$ \\
\hline
\end{tabular}

Means of each factor designated by the same latter are not significantly different at $5 \%$ level using Duncan's MRT.

Cultivar $\times$ phosphorus rate interaction $(\mathbf{C x P})$ : The grain yield of Giza 177 and sakha 104 was increased by increasing phosphorus rate from 0 to $36 \mathrm{~kg}$ $\mathrm{P}_{2} \mathrm{O}_{5} / \mathrm{ha}$ and then it decreased in the two seasons. However, increasing phosphorus rate from 0 to $54 \mathrm{~kg} \mathrm{P} \mathrm{O}_{5} /$ ha increased grain yield of $\mathrm{SK} 2034 \mathrm{H}$ and Giza 178 cultivars in both seasons. There was no significant difference between 36 and $54 \mathrm{~kg} \mathrm{P} \mathrm{O}_{5} / \mathrm{ha}$ in grain yield of Giza 178 cultivar in both seasons. The highest grain yield was obtained from SK2034H cultivar when it received $54 \mathrm{~kg} \mathrm{P}_{2} \mathrm{O}_{5} / \mathrm{ha}$, while the lowest one were obtained from Giza 177 rice cultivar without phosphorus fertilizer in both seasons. 
Table 7: Grain yield ( $t / h a)$ as affected by the interactions among rice cultivars, phosphors and zinc rates in 2008 season

\begin{tabular}{|c|c|c|c|c|c|c|}
\hline \multirow{2}{*}{$\begin{array}{c}\mathrm{P}_{2} \mathrm{O}_{5} \\
\text { (kg/ha) }\end{array}$} & \multirow{2}{*}{$\begin{array}{r}\mathrm{ZnSO}_{4} \\
\text { (kg/ha) }\end{array}$} & \multicolumn{5}{|c|}{ Rice cultivars } \\
\hline & & Giza177 & Giza178 & Sakha104 & Sk2034H & Mean \\
\hline \multirow{10}{*}{$\begin{array}{l}0 \\
18 \\
36 \\
54\end{array}$} & & \multicolumn{4}{|c|}{ Cultivar x phosphorus } & \\
\hline & & $4.50 i$ & $5.63 \mathrm{~g}$ & $4.71 \mathrm{hi}$ & $6.29 f$ & \\
\hline & & $5.01 \mathrm{hi}$ & 6.63 ef & $4.92 \mathrm{hi}$ & $6.89 \mathrm{de}$ & \\
\hline & & $5.56 \mathrm{~g}$ & $7.28 \mathrm{~cd}$ & $7.08 \mathrm{de}$ & $8.15 b$ & \\
\hline & & $5.06 \mathrm{~h}$ & $7.75 \mathrm{bc}$ & $5.67 \mathrm{~g}$ & $9.30 \mathrm{a}$ & \\
\hline & & \multicolumn{4}{|c|}{ Cultivar x zinc } & \\
\hline & 0 & $4.22 \mathrm{j}$ & $5.80 \mathrm{fgh}$ & $4.86 \mathrm{i}$ & $6.45 \mathrm{~d}$ & \\
\hline & 12 & $4.85 i$ & $6.40 \mathrm{de}$ & $5.45 \mathrm{gh}$ & $7.20 \mathrm{c}$ & \\
\hline & 24 & $5.30 \mathrm{hi}$ & $7.14 \mathrm{c}$ & 5.92 efg & $8.23 \mathrm{~b}$ & \\
\hline & 36 & $5.76 \mathrm{fgh}$ & $7.94 \mathrm{~b}$ & 6.17 def & $8.75 \mathrm{a}$ & \\
\hline \multirow{6}{*}{0} & & \multicolumn{4}{|c|}{ Cultivar x phosphorus x zinc } & $\mathbf{P} \times$ zinc \\
\hline & 0 & $3.81 u$ & $4.9 \mathrm{~m}-\mathrm{u}$ & $4.3 \mathrm{st}$ & $5.4 \mathrm{k}-\mathrm{u}$ & $4.62 \mathrm{i}$ \\
\hline & 12 & $4.52 p-u$ & $5.26 \mathrm{k}-\mathrm{u}$ & $4.69 \mathrm{n}-\mathrm{u}$ & $6.05 \mathrm{i}-\mathrm{u}$ & $5.13 \mathrm{~h}$ \\
\hline & 24 & $4.68 n-u$ & $5.97 \mathrm{i}-\mathrm{u}$ & $4.69 n-u$ & 6.86 e-o & $5.55 \mathrm{~g}$ \\
\hline & 36 & $5.00 \mathrm{I-u}$ & $6.36 \mathrm{~h}-\mathrm{t}$ & $5.13 \mathrm{I}-\mathrm{u}$ & 6.85 e-o & $5.83 \mathrm{fg}$ \\
\hline & 0 & $4.14 \mathrm{tu}$ & $5.70 \mathrm{j}-\mathrm{u}$ & $4.43 r-u$ & $5.81 \mathrm{i}-\mathrm{u}$ & $5.02 \mathrm{~h}$ \\
\hline \multirow{4}{*}{18} & 12 & 4.65 o-u & 6.32 i-t & $4.82 \mathrm{~m}-\mathrm{u}$ & $6.50 \mathrm{~g}-\mathrm{s}$ & $5.57 \mathrm{~g}$ \\
\hline & 24 & $5.16 \mathrm{I}-\mathrm{u}$ & 7.02 e-m & $5.18 \mathrm{I}-\mathrm{u}$ & $7.24 \mathrm{~d}-\mathrm{I}$ & 6.15 ef \\
\hline & 36 & $6.08 \mathrm{i}-\mathrm{u}$ & 7.46 c-k & $5.26 \mathrm{k}-\mathrm{u}$ & 8.04 b-i & $6.71 \mathrm{~d}$ \\
\hline & 0 & $4.47 \mathrm{q}-\mathrm{u}$ & $6.63 \mathrm{f}-\mathrm{r}$ & $5.66 \mathrm{j}-\mathrm{u}$ & 6.76 e $-p$ & $5.88 \mathrm{fg}$ \\
\hline \multirow{4}{*}{36} & 12 & $5.31 \mathrm{k}-\mathrm{u}$ & 6.99 e-m & 7.02 e-m & $7.46 \mathrm{c}-\mathrm{k}$ & $6.70 \mathrm{~d}$ \\
\hline & 24 & $6.01 \mathrm{i}-\mathrm{u}$ & 6.94 e-n & 7.08 e-m & 8.87a-e & 7.22 c \\
\hline & 36 & $6.43 \mathrm{~g}-\mathrm{s}$ & 8.56 a-h & 8.56 a-h & $9.50 \mathrm{abc}$ & $8.26 \mathrm{a}$ \\
\hline & 0 & $4.47 \mathrm{q}-\mathrm{u}$ & $5.97 \mathrm{i}-\mathrm{u}$ & $5.00 \quad \mathrm{I}-\mathrm{u}$ & 7.82 b-j & $5.81 \mathrm{fg}$ \\
\hline \multirow{3}{*}{54} & 12 & $4.92 \mathrm{~m}-\mathrm{u}$ & 7.02 e-m & $5.26 \mathrm{k}-\mathrm{u}$ & $8.81 \mathrm{a}-\mathrm{f}$ & $6.50 \mathrm{de}$ \\
\hline & 24 & $5.35 \mathrm{k}-\mathrm{u}$ & 8.62 a-g & $6.72 \mathrm{e}-\mathrm{q}$ & $9.94 \mathrm{ab}$ & $7.66 \mathrm{~b}$ \\
\hline & 36 & $5.51 \mathrm{k}-\mathrm{u}$ & 9.37 a-d & $5.70 \mathrm{j}-\mathrm{u}$ & $10.6 \mathrm{a}$ & $7.80 \mathrm{~b}$ \\
\hline
\end{tabular}

Means of each factor designated by the same latter are not significantly different at $5 \%$ level using Duncan's MRT.

Cultivar $\times$ zinc rate interaction $(\mathbf{C x Z})$ : The highest grain yield was produced from SK2034H under $36 \mathrm{~kg} \mathrm{ZnSO} / \mathrm{ha}$, while the lowest one was produced from Giza 177 without zinc fertilizer.

Phosphorus rate $\times$ zinc rate interaction $(\mathbf{P x Z})$ : The highest grain yield was produced from application of $36 \mathrm{~kg} \mathrm{P}_{2} \mathrm{O}_{5} / \mathrm{ha}$ and $36 \mathrm{~kg} \mathrm{ZnSO}_{4} / \mathrm{ha}$, while the lowest ones were obtained from control treatment (without phosphorus and zinc application).

Cultivar $\times$ Phosphorus rate $\times$ zinc rate interaction $($ CxPxZ): The highest grain yield was produced from SK2034H fertilized by $54 \mathrm{~kg} \mathrm{P}_{2} \mathrm{O}_{5}$ and $36 \mathrm{~kg}$ $\mathrm{ZnSO}_{4} / \mathrm{ha}$, while the lowest ones were obtained from Giza177 without phosphorus and zinc application in the two seasons.

\section{Chemical Composition:}

Means of $\mathrm{P}, \mathrm{N}$ and protein content in grains of some rice cultivars as affected by phosphors and zinc rates and their interaction are presented in Table 8.

\section{Rice cultivars performance:}

Rice cultivars exhibited significant differences in $\mathrm{P}, \mathrm{N}$ and protein content in grains in both seasons. The hybrid rice cultivar SK2034H was 
Gharib, H. S. et al.

significantly superior to the other cultivars in all mentioned traits in both seasons.

Table 8: Phosphorus, nitrogen and protein content in grains of some rice cultivars as affected by phosphors and zinc rates and their interaction in 2007 and 2008 seasons

\begin{tabular}{|c|c|c|c|c|c|c|}
\hline \multirow{2}{*}{ Factor } & \multicolumn{2}{|c|}{ Phosphorus content } & \multicolumn{2}{|c|}{ Nitrogen content } & \multicolumn{2}{|c|}{ Protein content } \\
\hline & 2007 & 2008 & 2007 & 2008 & 2007 & 2008 \\
\hline Cultivar (C): & & & & & & \\
\hline$\overline{\text { Giza } 177}$ & $0.179 \mathrm{c}$ & $0.171 \mathrm{c}$ & $1.101 \mathrm{c}$ & $1.165 c$ & $6.158 c$ & $6.513 \mathrm{c}$ \\
\hline Giza 178 & $0.192 b$ & $0.184 b$ & $1.265 b$ & $1.305 b$ & $7.071 \mathrm{~b}$ & $7.296 \mathrm{~b}$ \\
\hline Sakha104 & $0.176 c$ & $0.167 \mathrm{c}$ & $1.265 b$ & $1.314 b$ & $7.075 b$ & $7.341 b$ \\
\hline $\begin{array}{l}\text { SK2034H } \\
\text { F test }\end{array}$ & $\underset{* *}{0.213 a}$ & $\underset{* *}{0.224 a}$ & ${ }_{* \star}^{1.322 a}$ & ${ }_{* *}^{1.383 a}$ & $\underset{* *}{7.387 a}$ & $\underset{* *}{7.729 a}$ \\
\hline $\mathrm{Kg} \mathrm{P}_{2} \mathrm{O}_{5} / \mathrm{ha}(\mathrm{P}):$ & & & & & & \\
\hline 0 & $0.164 d$ & $0.157 d$ & $1.130 d$ & $1.179 d$ & $6.317 d$ & $6.586 \mathrm{~d}$ \\
\hline 18 & $0.181 \mathrm{c}$ & $0.176 \mathrm{c}$ & $1.219 c$ & $1.271 \mathrm{c}$ & $6.809 c$ & $7.108 \mathrm{c}$ \\
\hline 36 & $0.198 b$ & $0.200 \mathrm{~b}$ & $1.276 b$ & $1.324 b$ & $7.133 b$ & $7.399 b$ \\
\hline 54 & $0.216 a$ & $0.214 a$ & $1.329 a$ & $1.393 a$ & $7.432 \mathrm{a}$ & $7.785 a$ \\
\hline $\mathrm{F}$ test & $* *$ & & & & & \\
\hline $\mathrm{Kg} \mathrm{Zn} \mathrm{SO}_{4} / \mathrm{ha} \mathrm{(Z):}$ & & & & & & \\
\hline 0 & $0.203 a$ & $0.211 a$ & $1.051 \mathrm{c}$ & $1.106 \mathrm{~d}$ & $5.877 \mathrm{c}$ & $6.179 d$ \\
\hline 12 & $0.198 b$ & $0.198 b$ & $1.211 b$ & $1.257 \mathrm{c}$ & $6769 \mathrm{~b}$ & $7.029 c$ \\
\hline 24 & $0.185 c$ & $0.188 \mathrm{c}$ & $1.332 a$ & $1.378 b$ & $7.447 a$ & $7.703 b$ \\
\hline 36 & $0.173 d$ & $0.166 d$ & $1.359 a$ & $1.425 a$ & $7.598 a$ & $7.968 a$ \\
\hline $\mathrm{F}$ test & $* *$ & $* *$ & $* *$ & $* *$ & $* *$ & $* *$ \\
\hline Interaction: & & & & & & \\
\hline$C \times P$ & ** & NS & NS & * & NS & * \\
\hline$C \times Z$ & $* *$ & NS & NS & NS & NS & NS \\
\hline$P \times Z$ & NS & $* *$ & * & NS & * & NS \\
\hline$P \times Z \times C$ & NS & NS & NS & NS & NS & NS \\
\hline
\end{tabular}

${ }^{*},{ }^{* *}$ and NS indicate $P<0.05, P<0.01$ and not significant, respectively. Means of each factor designated by the same latter are not significantly different at $5 \%$ level using Duncan's MRT.

Giza178 and Sakha104 cultivars, being insignificant, followed SK2034H and surpassed Giza177 in grain nitrogen and protein content in both seasons. The lowest values of phosphorus content were produced from Sakha104 without significant difference with Giza177 cultivar in the two seasons. However, The lowest values of nitrogen and protein content were obtained from grains of the cultivar Giza177 in the two seasons. The superiority of the hybrid rice cultivar SK2034H in this trait might be due to its large ability for increasing nutrient uptake and its great heterosis and salt tolerance and in turn increased phosphorus and nitrogen content in grains. Previous researchers found varietal differences in P-content (Tomar et al, 1994 and Zayed et al, 2010), N-content (El-kady and Abd EL-Wahab 1999) and protein content (Ram et al, 1997 and Zayed et al, 2007).

\section{Effect of phosphorus rate:}

Phosphorus, nitrogen and protein contents in rice grains were gradually increased by each increment of phosphorus fertilizer in the two seasons. This is mainly due to the increase in soluble phosphates under higher rate of phosphorus application, which increased phosphorus and nitrogen uptake and in turn grain $\mathrm{P}$ and $\mathrm{N}$ content and consequently protein. 
In this connection, Prakash and Badrinath (1995), Brohi et al (1998), Masthan et al (1998) and Zayed et al (2010) found that N and P-content of of rice grain were increased by increasing phosphorus rate. Zayed et al (2010) added that increasing phosphorus rate increased crude protein content in rice grains under saline soil.

\section{Effect of zinc rate:}

Zinc application had an opposite effect on phosphorus content of rice grains in the two seasons. Phosphorus content of grains was gradually decreased by increasing zinc rate from 0 to $36 \mathrm{~kg} \mathrm{ZnSO} 4 / \mathrm{ha}$. This is mainly due to the antagonistic effect between phosphorus and zinc. Tomar et al (1994) and Taban (1995) came to the same conclusion. However, Zinc application resulted in a considerably increase in nitrogen and protein content of rice grains compared with control treatment (without zinc fertilizer) in the two seasons. Application of zinc at the rate of $36 \mathrm{~kg} \mathrm{ZnSO} / \mathrm{ha}$ produced the highest nitrogen and protein content of grains in the two seasons. The rates of 24 and $36 \mathrm{~kg} \mathrm{ZnSO} / / \mathrm{ha}$ did not differ in this respects in the first season. The favorable effect of zinc fertilization on these traits was viewed by Chen and Fan (1997) and Ranjha et al (2001).

\section{Effect of interaction:}

The interactions of cultivar $\times$ phosphorus rate for phosphorus content in rice grains in the first season, nitrogen and protein content in the second season; cultivar $\times$ zinc rate for phosphorus content in rice grains in the first season and phosphorus rate $\times$ zinc rate for phosphorus content in grains in the second season, nitrogen and protein content in the first season were significant.

It can be concluded that sowing $\mathrm{SK} 2034 \mathrm{H}$ rice cultivar and application phosphorus fertilizer at the rate of $54 \mathrm{~kg} \mathrm{P}_{2} \mathrm{O}_{5} / \mathrm{ha}$ and Zinc fertilizer at the rate of 24 or $36 \mathrm{~kg} \mathrm{ZnSO} 4$ could be recommended to produce optimum grain yield per unit area under saline soil condition.

\section{REFERENCES}

Abou-Khalifa, A.A.(2005). Physiological behiver of some rice cultivar under different sowing dates and seedling age .The $11^{\text {th }}$ conference of agronomy, Nov.15-16, Agron. Dept., Fac. Agric., Assuit Univ., p.315-327

Alam, M.M.; M. Hasanuzzaman and K. Nahar (2009).Tiller dynamics of three irrigated Rice varieties under varying phosphorus levels. AmericanEurasian J. Agron., 2 (2): 89-94.

Ali, M.M; M.S.Mian; A. Islam; J.A.Begumand; A.K. M.Ferdous (2004). Interaction effect of sulphur and phosphorus on wetland rice. Asian j. plant sci., 3 (5):597-601.

Ali, Q. and Z.A. Ansari (2006). Phosphorus requirements of rice grown in soils with different sodicity. J. Plant Nutrition, 29(12): 2105 - 2117.

Ashraf, M. (2004). Some important physiological selection criteria for salt tolerance in plants. Flora, 199: 361-376.

Bharat, S. (2006). Response of rice to nutrients in salt soil. Farm Sci. J.,15(1):15-16. 
Biswas, D.R. and M.S. Dravid (2001). Phosphorus and zinc interaction as influenced by magnesium on yield and nutrient uptake by rice under varying moisture regimes. Annals Agric. Res., 22(3):329- 334.

Black, C.A., D.D. Evans, L.E. Ensminger and F.E. Clark (1965). Methods of Soil Analysis. Part 2- Chemical and microbiological properties. American Soc. of Agronomy, Inc., Publisher, Madison, Wisconsin, USA.

Brohi, A. R.; M.R. Karaman; A. Aktas, and E. Savasli (1998). Effect of nitrogen and phosphorus fertilization on the yield and nutrient status of rice crop grown on artificial siltation soil from the Kelkit River. Turkish J. Agric. Forestry, 22(6):585-592.

Chapman, H.D. and P.F. Pratt (1961). Methods of analysis for soils, plant and water. Univ. of California, Berekely, USA.

Chen, L.J. and X.M. Fan (1997). Grain quality response to phosphorus and zinc fertilizer in rice genotype. Chinese Rice Res. Newsletter, CRRN., 5(3):9-10.

Coutinho, E.L.M.; A.A. Otsubo; C. de S. Martins; G.F. Childs (1992). Response of rice (Oryza sativa L.) to fertilization with zinc. Revista de Agricultura Piracicaba, 67(6):1-12.

Duncan, D.B. (1955). Multiple Range and Multiple F. Test. Biometrics. 11: 1-42.

EL-Kady, A.A. and A.E Abd EL-Wahab (1999). Nitrogen fertilizer management and its effect on growth, yield and grain quality of some Egyptian rice. Egypt. J. Appl. Sci., 14(7): 26-35.

Gautam, A.K (2004) Effect of nitrogen level and spacing on productivity and quality of inbred and hybrid aromatic rice. Ph.D. Thesis, Agron., Indian Agric., Res. Instit., New Delhi, India.

Ghose, T.J.; P.K. Borkakati; N.G. Barua; A.K. Pathak and R.K. Chowdhury (1999). Effect of varying levels of zinc and phosphorus in kharif rice of Upper Assam. Indian J. Hill Farming, 12: 17-21.

Gomez, K.A. and A.A Gomez (1984). Statistical procedures for agricultural research. $2^{\text {nd }}$ Ed. John Wiley and Sons, New York, USA.

Heluf G. and M. Seyoum (2006). Effects of mineral N and P fertilizers on yield and yield components of flooded lowland rice on vertisols of fogera plain. Ethiopia J. Agric Rural Develop. in the Tropics and Subtropics, 107(2):161-176.

Hood, M. (2002). Rice response to phosphorus and zinc. Farmers Newsletter, 160: 34-35.

Hussain, F. (2004). Soil fertility monitoring and management in rice-wheat system. Annual report, 2003-04 of the agriculture linkages program Project at land resources research program, National Agric. Res. Centre Islamabad, Pakistan.

Ibrahim, R. (2001). Effects of nitrogen and phosphorus levels on yield and yield components of three upland rice (Oryza sativa L.) varieties at Samaru, Nigeria.ASSET-Series-A:-Agriculture-and-Environment.,1(2): 115-119.

Kaya, C.; B.E. Ak and D. Higgs (2003). Response of salt stressed strawberry plants to supplementary calcium nitrate and/or potassium nitrate. J. Plant Nutr. 26(3): 543-560. 
Khan R.; A.R. Gurmani; M.S. Khan and A.H. Gurman (2009). Residual, direct and cumulative effect of zinc application on wheat and rice yield under rice-wheat system. Soil Environ., 28(1): 24-28.

Kumar, S. and R.S. Singh, (2001). Phosphorus management in rice-wheat cropping system. J. Res.Birsa Agric. Univ.,13(1):51-56

Malavolta, E.; R. Heinrichs; C.P. Cabral,; S.C. de Oliveira; G. Szakacs; J.F. de A. Netto; R.S. de Almeida; W.J.O. Souza, and M. Malavolta (2002). Response of two rice (Oryza sativa L.) varieties to zinc in nutrient solution. Revista de Agricultura Piracicaba,77(2):195-208.

Masthan, S.C.; S.N. Reddy; M. Shaik and B. Vijaykumar (1998). Possibilities of economizing phosphate fertilizer in rice- groundnut-greengram crop sequence. Inter. J. Tropical Agric., 15: 223-228.

Munns, R.; R.A. James and A. Lauchli (2006). Approaches to increasing the salt tolerance of wheat and other cereals. J. Exp. Bot., 57(5): 1025-1043.

Panda, S.C.; P.C. Panda and S.S. Nanda (1995). Effect of levels of N and P on yield and nutrient uptake of rice. Oryza, 32:18-20

Pitman, M. G. and A. Lauchli (2002). Global impact of salinity and agricultural ecosystems. In: Salinity: Environment-Plants-Molecules. (Eds.): A. Läuchli \& U. Lüttge. Dordrecht, the Netherlands: Kluwer, pp. 3-20

Prakash, T.R. and M.S. Badrinath,(1995). Effect of phosphates with lime on the nutrient availability and uptake by rice on an Ultisol. J. Indian Society Soil Sci.,43 (3):472-473.

Ram, S.; R.P.S.Chauhan,; B.B. Singh and V.P. Singh (1997). Response of wet-season rice (Oryza sativa) to nitrogen and phosphorus in partially reclaimed sodic soil. Indian J. Agric Sci.,67(11): 514-517.

Ranjha, A. M.; A.lftikhar; M. lqbal and M.J. Ahmed (2001). Rice response to applied phosphorus, zinc and farmyard manure. Inter. J. Agric. Biol.,3 (2):197-198.

Rao, C.P. and D.N. Shukla, (1999). Yield and nutrient uptake of rice (Oryza sativa) as influenced by sources and levels of phosphorus and zinc under transplanted conditions. Indian J. Agron., 44(1):94-98.

Shehata S.M.; B.A. Zayed; E.S. Naeem; S.E.M. Seedek and A.A. EL-Gohary (2009). Response of rice (Oryza sativa) to different levels of Zinc and sulfur under saline soil. Egypt j. Appl. Sci,24(12):551-565.

Singh, T.; Y.S. Shivay and S. Singh (2004). Effect of date transplanting and nitrogen on productivity and nitrogen use indices in hybrid and nonhybrid aromatic rice. Acta Agronomica Hungarica,52(3):245-252.

Suriya-arunroj, D.; P. Chaiyawat; S. Fukai and F.P.C. Blamey (2000). Identification of nutrients limiting rice growth in soils of Northeast Thailand under water-limiting and non-limiting conditions. Plant Production Sci.,3(4): 417-421.

Taban, S.(1995). Effects of increasing zinc application rates on the nitrogen, phosphorus and potassium contents of rice plants. Turkish J. Agric Forestry, 19(2):119-125.

Tariq, M.; S. Hameed; K.A. Malik and F.Y. Hafeez (2007). Plant root associated bacterial for zinc mobilization in rice. Pak. J. Bot., 39 (1): 245-253. 
Gharib, H. S. et al.

Tomar, P.S.; A. Upadhyay and J.K. Sharma (1994). Effect of zinc on yield and nutritional quality of grain and straw of rice cultures. Annals of Plant Phys.,8(1):66-68.

Watanabe, F.S. and S.A. Olson (1965). Colorimetric determination of phosphorus in water extract. Soil Sci., 93:183-188.

Wilson, C.E.; N.A. Slaton; S. Ntamatungiro; D.L. Frizzell; W.B. Koen and R. J. Normas (1999). Phosphorus fertilize recommendations for rice. Better Crops, 83 (4):9-11.

Zayed, B.A.; A.E. Abd El Wahab; A.O. Basttawisi; A.M. Hagras and H.F.W. El-Mowafi (2006). Physiology response of some hybrid and inbred rice varieties to different times of nitrogen application and plant geometry. First Filed Crop Conference, 22-24 Agust Giza, Egypt, pp.533-542.

Zayed, B.A.; I.S .El-Rafaee and S.E. Sedeek (2010). Response of different rice varieties to phosphorus fertilizer under newly reclaimed saline soil. J. Plant Prod. Mansoura Univ.,1 (11):1479-1493.

Zayed, B.A.; W.M. Elkhoby; S.M. Shehata and M.H. A emmar (2007). Role of potassium application on the productivity of some inbred and hybrid rice varieties under newly reclaimed saline soils $8^{\text {th }}$ African crop science society conference, 27-31 October, El-Minia, Egypt, (1):55-60.

Zia, M.S.; M. Aslam; M.B. Baig and A. Ali ( 2000). Fertility issues and fertilizer management in rice-wheat system: A review. Quality Science Vision (COMSATS, Islamabad) 5: 59-73.

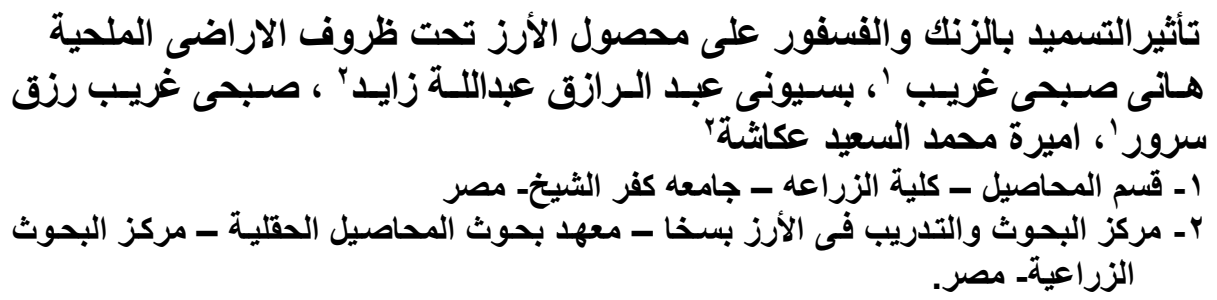

أجريت تجربتان حقليتان بالمزر عة البحثية بمحطة البحوث الزراعية بالسرو بمحافظة دمياط خلال البرال

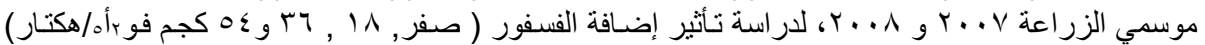

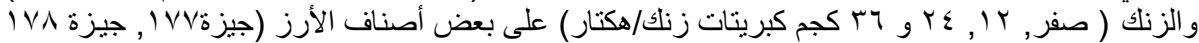

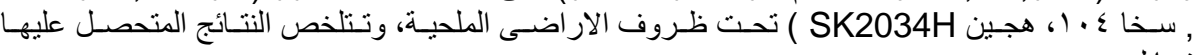
فيمايلى:

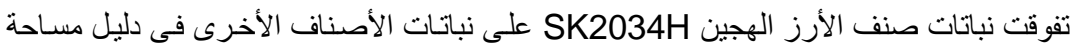

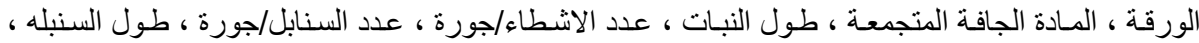

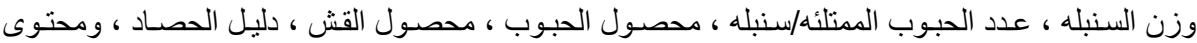

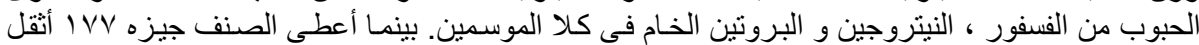

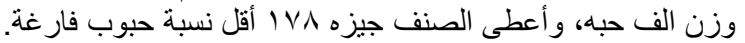

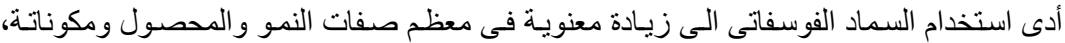

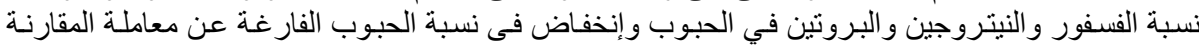

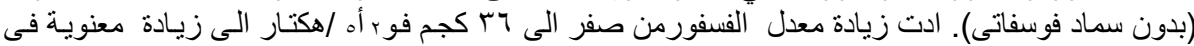

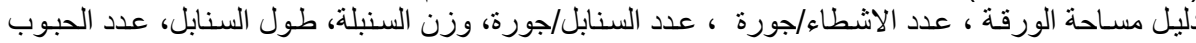

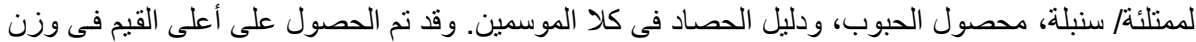




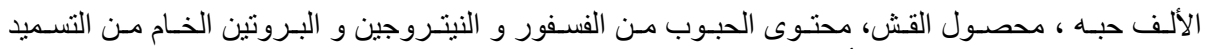

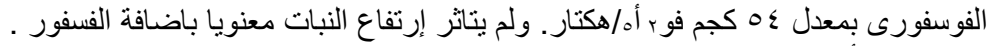

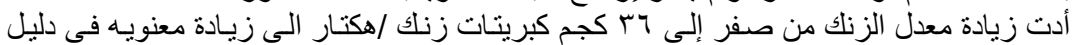

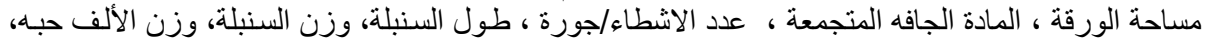

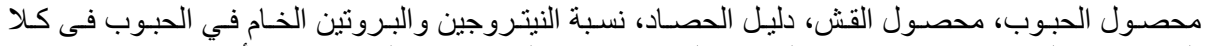

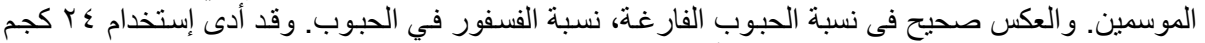

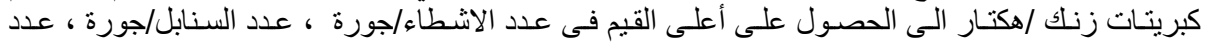

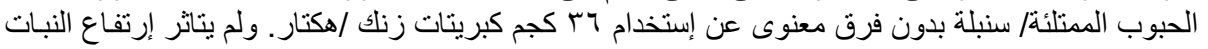
معنويا باضافة الزنك.

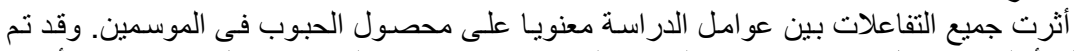

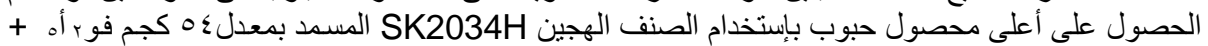

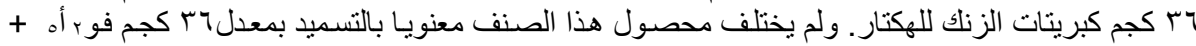

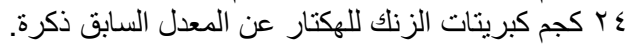

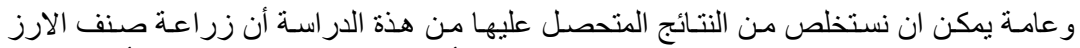

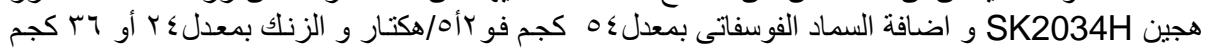

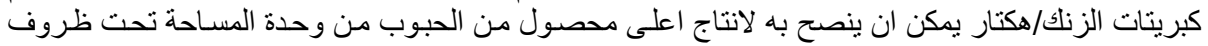
الار اضى الملحية.

كلية الزراعة - جامعة المنصورة كلية الزراعة - جامعة كفر الشيخ 